IFN Working Paper No. 952, 2013

\title{
Employment Protection and Parental Child Care
}

Martin Olsson 


\title{
Employment protection and parental child care`
}

\author{
by \\ Martin Olsson* \\ January 28, 2013
}

\begin{abstract}
I examine if employment protection affects parental childcare. I find that a softer employment protection has a substantial effect on how parents use and divide paid childcare between them. The identification relies on a reform that made it easier for employers in Sweden to dismiss workers in small firms. I estimate that a softer employment protection reduces the total days of parental childcare in targeted firms, measured as total days of parental leave or temporary parental leave. Both a sorting effect and a behavioral effect can explain the reduced childcare. I also find evidence of a redistribution effect of paid parental childcare within households if only one partner was affected by the reform. I interpret the redistribution effect as a way of evading an external cost on the child.
\end{abstract}

Keywords: employment protection; parental childcare; within family distribution JEL-codes: J13; K13

\footnotetext{
• I wish to thank Anders Björklund, Johan Egebark, Michael Gähler, Andrea Ichino, Per Johansson, Erik Lindqvist, Lars Persson, Per Pettersson-Lidbom, Per Skedinger, Peter Skogman Thoursie, Helena Svaleryd, and participants at EALE 2011 and SOLE 2012 for valuable comments. Financial support from the Jan Wallander and Tom Hedelius Foundation and FAS (Dnr 2004-2005) are gratefully acknowledged.

* Research Institute of Industrial Economics (IFN), Stockholm, Sweden. Email: martin.olsson@ifn.se.
} 


\section{$1 \quad$ Introduction}

The dual earner family has become the most common family form in developed countries today. ${ }^{1}$ Consequently, the importance of being able to combine work and family has increased. ${ }^{2}$ In the European Union, reconciliation of work and family has been on the political agenda since the mid 1980's and is today stated in the Lisbon Treaty. ${ }^{3}$ More explicitly, family policies such as parental leave and subsidized childcare have been implemented to help parents juggle work and family. Economic research has shown that fertility as well as the use of paid parental childcare can be affected by family policies. ${ }^{4}$ But how non-family friendly labor market institutions influence working parents is less understood, though a good understanding of their effects ought to be fundamental for creating a successful reconciliation of work and family.

In this study, I examine the impact of employment protection on working parents' willingness to provide childcare. The level of employment protection is directly linked to the risk of being dismissed if an employee is absent and has been shown to affect workers' absence behavior. ${ }^{5}$ Besides the insight that the use of sickness absence is affected, little is known of how employment protection affects other types of behavior.

To understand if employment protection influences parental childcare, I analyze an exemption in a seniority rule that made the employment protection softer in firms with two to ten employees in Sweden. The seniority rule is applied if a firm has shortage of work and specifies the dismissal order in accordance with workers' firm-specific tenure. Starting in 2001, firms with two to ten employees can exempt two workers from the tenured-based dismissal order. Since the exemption only increases the number of workers at risk for being dismissed in small firms it creates within country variation in employment protection and thereby an opportunity to overcome the fact that a worker's

\footnotetext{
${ }^{1}$ The dual earner family is the most common family form in a majority of the OECD countries (OECD (2010)). In 2007, the median employment rate for partnered mothers aged 15-64 was 66.5 percent in the OECD countries. For the U.S., the Current Population Study for 2008 shows that 57.3 percent of all married-couple families were dual earner families.

${ }^{2}$ The Economist, Dec 30th 2009, “Female Power” writes: “Many women - and indeed many men - feel they are caught in an ever-tightening tangle of commitments. If the empowerment of women was one of the great changes of the past 50 years, dealing with its social consequences will be one of the great challenges of the next 50 .”

3 The legislation is stated in article 33 of the Charter of Fundamental Rights in the Lisbon treaty. Since 2002, reconciliation of work and family is also one of three main objectives in the EU gender policy.

${ }^{4}$ For instance, Lalive and Zweimüller (2009) provide evidence that job protected parental leave has a positive effect on fertility and mothers' time between birth and return to work. Skyt-Nielsen (2009) and Ekberg et al (2005) find that family policies can affect the within household distribution of parental leave by introducing economic incentives or by earmarking certain days to the father A reason for parents to be unwilling to provide childcare is that a career interruption can have a negative effect on subsequent earnings as discussed by Albrecht et al (1999).

${ }^{5}$ See Riphahn and Thalmaier (2001), Ichino and Riphahn (2005), Lindbeck et al (2006), Olsson (2009) and Jacob (2010). See also Engellandt and Riphahn (2005) for how worker effort in terms of unpaid overtime may vary with employment protection.
} 
level of employment protection is not random. The reform of the seniority rule has been shown to decrease the sickness absence in small firms (Lindbeck et al (2006) and Olsson (2009)) and increase hires and separations in small firms (von Below and Skogman Thoursie (2010)).

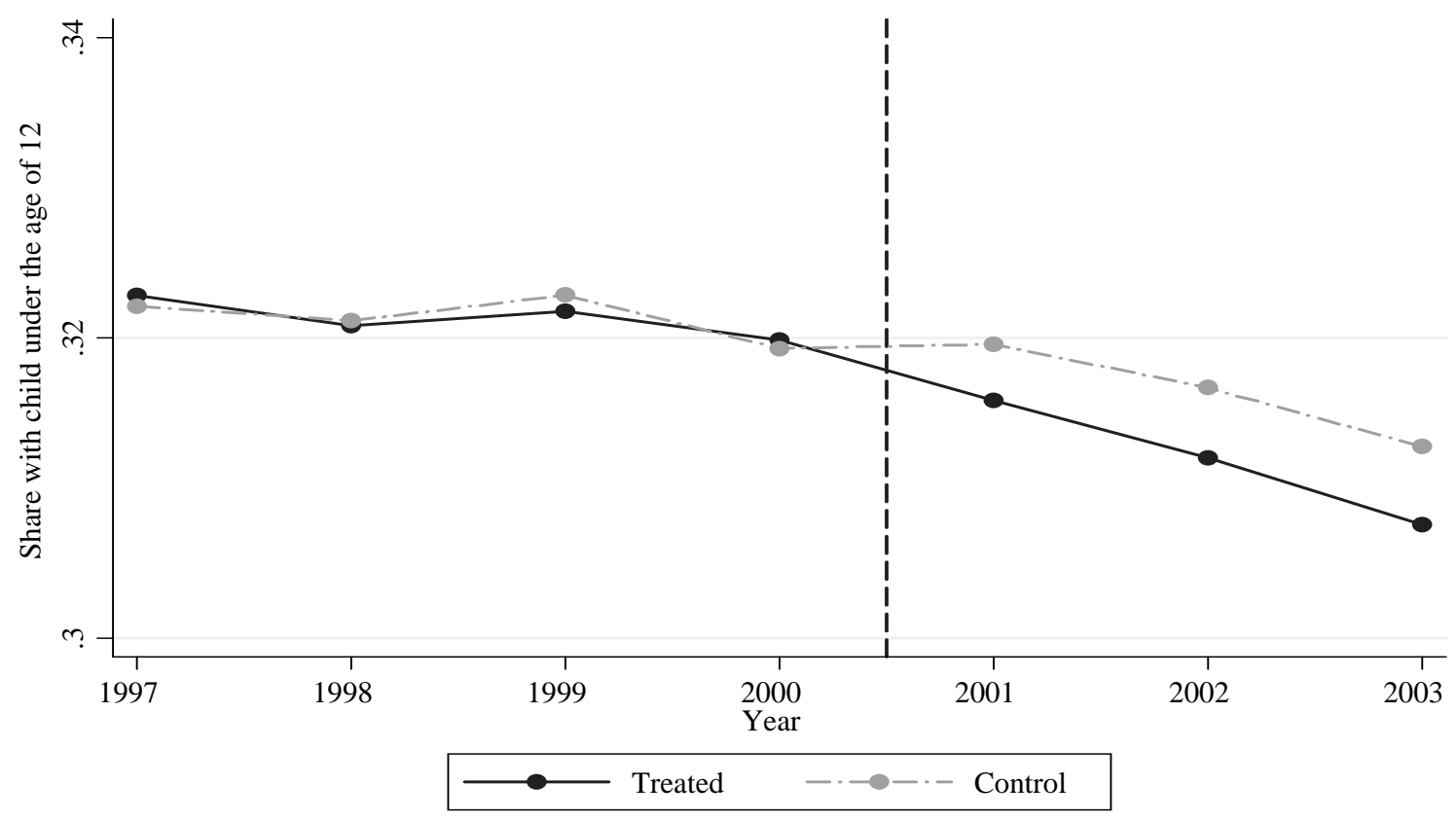

Figure 1 Share of employees having a child under the age of twelve in treated and control firms from 1997 to 2003

Notes: The figure uses a repeated cross-sectional sample where firm size is measured as the average yearly number of employees. "Treated" refers to firms with two to ten employees and "control" refers to firms with eleven to 20 employees.

This paper focuses on working parents and their use of paid childcare. In general, parenthood implies absence from work when caring for the child. To the extent that employers dislike absence periods, one can expect working parents, as a group, to be extra sensitive to softer employment protection. For instance, a softer protection can lead to dismissals of working parents if employers favor workers that are less absent, or working parents may seek jobs with a higher level of protection to avoid a dismissal. In Figure 1, it is seen that the share of employees with young children drops by 1.4 percent on average ( 0.45 percentage points) in firms with two to ten employees in the periods following the reform in $2001 .^{6}$ Figure 1 indicates that working parents may be sensitive to softer employment protection.

\footnotetext{
${ }^{6}$ The decline of 1.4 percent refers to the drop relative to the pre-reform average for the treatment group.
} 
To measure parental childcare, I use comprehensive data on paid parental leave and temporary parental leave (care of a sick child) combined with detailed individual information for the whole Swedish working population. The connection between employment protection and parental childcare is investigated with a difference-indifference strategy that compares childcare for workers in firms with two to ten employees with childcare for workers in firms with eleven to 50 employees, before and after the reform in 2001. I conduct a graphical analysis that shows that the groups have similar trends in key outcomes prior to the reform, which suggests that my results can be interpreted as causal.

I find that a softer employment protection reduces parental childcare. More specifically, I estimate that a softer employment protection reduces the total days of paid parental leave by on average 10.6 percent among workers in treated firms. The decline in total days of temporary parental leave is estimated to 5.5 percent. Two mechanisms can explain the decline: a sorting effect that changes the worker composition in targeted firms and a behavioral effect that changes working parents' willingness to provide childcare. Parents' relative employment protection seem important for the within family distribution of childcare. I estimate that in families where one partner got a softer employment protection, the use of parental childcare increased in general for the unaffected male partner in reaction to the softer protection for the other partner.

This study provides evidence that labor market institutions unrelated to family policies can be important for parents' willingness to provide paid childcare. While this seems obvious, it has attracted little attention so far. I present three novel findings. First, I estimate that a softer employment protection makes working parents less willing to provide paid childcare. This extends the literature on how employment protection affects workers' behavior where sickness absence has been assessed earlier (Riphahn and Thalmaier (2001), Ichino and Riphahn (2004, 2005), Lindbeck et al (2006), Olsson (2009) and Jacob (2010)). Second, I show that a softer employment protection in certain firms can offset a sorting effect that alters the composition of the workforce in targeted firms in such a way that average parental childcare among employees is decreased. This confirms that employment protection can affect groups of workers differently (Delacroix (2003) and Kugler and Saint-Paul (2004)). Third, I find empirical support for the fact that the intra-household distribution of childcare is partly based on parents' relative degree of employment protection which relates to the literature on how 
distributional factors can change the relative bargaining power within families (see Browning and Chiappori (1998), Chiappori, Fortin, and Lacroix (2002), and Chiappori and Ekeland (2006) for how the distributional factor affects spouses' relative bargaining strength, and in particular Parys and Schwerhoff (2010) for how distributional factors can affect the within family distribution of parental leave).

\section{Institutional setting}

In this section, I briefly describe the Swedish employment protection legislation with a focus on the seniority rule and how it was reformed in 2001. I also describe the general outline of the Swedish parental insurance system.

\subsection{The employment protection legislation and the reform}

The Swedish employment protection legislation act, Lagen om anställningsskydd, was introduced in 1974 and regulates three areas: regular employment, temporary employment, and collective dismissals. A debated part of the legislation is the seniority rule that stipulates the tenured-based order of dismissal at times of redundancies. The rule is often referred to as the "last-in-first-out"-rule as it states, somewhat simplified, that the last worker that was hired should be the first worker to be dismissed. ${ }^{7}$ The rule includes all workers apart from family members of the firm owner and those in managerial positions and is applied within job task-specific groups at a firm. ${ }^{8}$ The seniority based dismissal order was introduced to reduce the risk for older workers to end up in permanent unemployment. ${ }^{9}$ A critique against the seniority rule is that employers can become reluctant to hire "wild cards”, such as young individuals and immigrants, since bad matches are hard to resolve. Proponents of the rule often emphasize that the rule is dispositive since collective-agreements allow departures from it. Whether the rule is strictly followed or not appears to be correlated with the number of employees in a firm: Calleman (1999) studies 30 Swedish workplaces in the years 1994 and 1995 to see how the seniority rule is applied and finds that it is only strictly followed in small workplaces where job tasks are similar (small in terms of the number of employees).

\footnotetext{
${ }^{7}$ If two workers have the same tenure, the oldest worker is prioritized.

${ }^{8}$ In Swedish, this is referred to as "turordningskretsar".

${ }^{9}$ A tenured-based dismissal order implies that employers cannot sort employees according to their productivity, as pointed out by Edin and Holmlund (1993). By having employees of different productivities share the unemployment risk, the signaling cost of unemployment becomes less costly since the signal contains less information about an employee's productivity.
} 
The aim of the reform in 2001 was to alleviate the cost of the seniority rule for smaller firms because a key worker was considered to be relatively more important for the operation of smaller firms. An amendment was thus added to the Swedish employment protection legislation in January 2001 that allowed firms with at most ten employees to exempt two workers of significant importance from the stipulated order of dismissal. The amendment came about through an unexpected collaboration between the Green Party and the non-socialist parties and was decided in October 2000. Lindbeck et al (2006) present the chronological order of the decision process. During the early spring of 2000, the discussion concerned whether to allow exemptions in all firms or only in firms with at most ten employees. In May the same year, it became clear that the first alternative could never be implemented, and it was not until October 2000 that it was finally decided that only small firms were to exempt two workers from the seniority rule.

Already in 1994, firms of any size were allowed to exempt two workers from the stipulated order of dismissal, but the exemption was abolished one year later when the Social Democratic Party came into power with the argument that the exemption had given employers too much power in their relationship to employees as employers were already able to decide when to dismiss workers due to shortage of work.

When a firm can exempt two workers from the seniority rule it increases the number of workers at risk of being dismissed. Before the reform, the seniority rule stipulated that only the worker with shortest tenure in a firm was at risk of being dismissed if one worker were to be dismissed and the rule was strictly applied. But after the reform the worker with shortest tenure shares the risk with the two workers who have the second and third shortest tenure in the firm. For all of these workers the linkage between their productivity and continued employment became stronger. For the workers with second and third shortest tenure it get relative more important to signal a high effort or high productivity to remain employed and the worker with shortest tenure gets a greater a chance to remain employed at times of shortage of work as the least tenured worker can be exempted from the seniority rule based dismissal order. By signaling a high effort or productivity the worker with shortest tenure can affect the probability to remain employed.

If employers dislike workers who are absent, exempting two workers from the seniority rule can, in particular, trouble working parents. The reason is that parenthood often comes with an increase in absence when caring of the child and employers can use 
the exemption of the seniority rule to exempt workers in such a way that working parents are dismissed to a greater extent. ${ }^{10}$ If parents feel that the use of paid parental childcare during working hours can have a negative effect on their future employment they may react by reducing their use of paid childcare.

Earlier studies show that the reform of the seniority rule had an impact on both workers and employers: Lindbeck et al (2006) and Olsson (2009) report that workers in eligible firms decreased their sickness absence once the reform was implemented and von Below and Skogman Thoursie (2010) discover that the reform increased hires and separations in small firms by five percent each. Moreover, when the Confederation of Swedish Enterprise in 2009 made a survey of 600 firms with five to ten employees, 32 percent of the 174 firms that reported that they had had displacements during the previous year claimed that they had made use of the exemption.

\subsection{The parental leave insurance}

The Swedish parental insurance system dates back to 1974 and provides economic compensation for foregone labor income when taking care of a child during regular working hours. ${ }^{11}$ The insurance covers parental leave and temporary parental leave (leave for care of a sick child) and it is generous in an international comparison. Job protected parental leave is provided during the first 18 months of a child's life. After that, parents are entitled to work part time (minimum one fourth of regular working hours) until the child turns eight. The parental leave insurance provides economic compensation for a total of 480 days per child and can be drawn until the child turns eight years old. For the first 390 days, the benefit amounts to around 80 percent of the yearly income (up to a cap of almost 432,000 SEK per year). Those with no or very low income are guaranteed 180 SEK per day called the basic level. For the last 90 days of the 480 days, a fixed amount of 180 SEK per day is paid. ${ }^{12}$ To encourage dual earner families, 60 days are earmarked for each parent. The earmarked days were introduced in

\footnotetext{
${ }^{10}$ Besides the decline of parents with children aged less than twelve years in eligible firms, see Figure 1, the Swedish Trade Union Organization (LO) claims that around half of all exemptions involving their members up until 2003 were unacceptable and involved in particular pregnant women, parents on parental leave and elderly workers (Arbetaren (2003)). Earlier experience of reforming the seniority rule also suggests that working parents can be negatively affected. In 1999, the Swedish ombudsman of equality (JämO) assessed the firm size neutral exemption of two workers introduced for one year in 1994. One of the main conclusions is that the exemption in 1999 had had a disproportionally negative effect on workers on parental leave and older women. There have also been three parliamentary bills with the objective to abandon the 2001-reform, all of them arguing that this does, in particular, hit pregnant women and employees on parental leave. Two bills came from members of the Social Democratic Party in 2001 and 2009, and one from members of the Left Party of Sweden in 2002.

11 Before 1974, only mothers were covered by the insurance.

12 Before 2003, the replacement for the last 90 days was 60 SEK.
} 
1995 with a so-called daddy month and were extended by an additional month in 2002. ${ }^{13}$ The use of parental leave among fathers has become more common over time: in 2007 around 21 percent of all paid parental leave days were taken by fathers, compared to around one percent in $1974 .{ }^{14}$

Parents with children aged less than 12 are eligible for temporary parental leave benefits. The insurance compensates parents for economic losses when staying home from work to take care of a sick child. The compensation rate is 80 percent and is paid for at most 120 days per year and child without any waiting period. To allow part-time work, benefits can be drawn for a full day, 3/4,1/2,1/4, or $1 / 8$ of a day. The use of temporary parental benefits is widespread: in 2009, 367543 mothers took a total of 2898916 days of temporary parental leave corresponding to an average of 7.7 days. ${ }^{15}$ In the same year, 271661 fathers took 1590462 days of temporary parental leave corresponding to 5.8 days. The total number of used temporary parental leave days was thereby 4489 378, corresponding to around one day of leave per person in the Swedish workforce per year.

The Swedish parental leave law states that employers cannot disfavor employees for reasons connected to parental leave. But employers with small firms need not to motivate why they exempt a worker from the seniority rule. Employers can thereby partly circumvent the parental leave law by systematically exempting workers in such a way that they are able to dismiss pregnant women or workers on parental leave, as argued by the Swedish Trade Union Organization (Arbetaren (2003)).

\section{Conceptual framework}

\subsection{The direct effect}

Employment protection is often justified on the basis that it protects employees from income fluctuations. But employment protection comes with side effects. Theoretically, employment protection increases a firm's adjustment cost and thereby also the matching of employers and employees. With rigid wages, the adjustment cost leaves some unproductive employer-employee matches unresolved and hinders some productive

\footnotetext{
${ }^{13}$ In 2002, an extra 30 days of leave were also added.

${ }^{14}$ These figures do not consider unpaid leave. In a survey made by the Swedish National Insurance Board, (2004) the correlation between the number of days on parental leave and days with paid parental benefits was 0.34 for mothers and 0.65 for fathers. So a third of the days a mother spends on leave are compensated compared to around two-thirds for fathers. Comparing used days of paid leave between parents is likely to not reflect the actual division of parental leave.

${ }^{15}$ The number of days is measured as net days so spells lasting $3 / 4,1 / 2,1 / 4$, or $1 / 8$ of a day are recalculated into whole day equivalents.
} 
employer-employee matches to occur. Hence, employment protection dampens job flows and worker flows on the labor market and can thereby affect the employment level (see, for example, Hopenhayn and Rogerson (1993), Mortensen and Pissarides (1999), Pries and Rogerson (2005)). Besides these outcomes, employment protection can affect productivity by distorting firms' choice of capital and labor in their production process (Wasmer (2006) and Autor et al (2007)), by providing workers with incentives to accumulate firm-specific human capital (Mortensen and Pissarides (1999)), and by influencing workers' absence behavior (Ichino and Riphahn (2005), Lindbeck et al (2006), Olsson (2009) and Jacob (2010)). ${ }^{16}$

The reform of the seniority rule in 2001 reduced the adjustment cost for small firms. I expect the lower adjustment cost to affect the use of childcare among workers in targeted firms in two ways: i) by sorting of workers that changes the composition of the workforce in small firms, and ii) by changing the behavior of existing workers. A negative sorting effect occurs if employers in small firms make use of the exemption to dismiss working parents that use more leave than the average worker at the firm. Also, workers in small firms who usually use paid childcare or intend to use paid childcare may move to employers not entitled to exempt workers from the seniority rule and thereby offsetting a negative sorting effect. ${ }^{17}$ Whether this last type of sorting effect is relevant is unclear since changing employer means that a worker will be the last worker at the new workplace and therefore may face a higher risk of being dismissed in the short run. But if workers get tenured relative faster in the new firm, the relative dismissal risk compared to the risk in the old firm can decrease in the long run. Moreover, when dismissals become easier, workers previously rejected on the basis of their current or expected future parental status can be employed (see Kugler and SaintPaul (2004) for a general discussion on employers' screening behavior and employment protection). Less careful screening may raise the average use of paid childcare among employees. The overall effect from sorting of workers is ambiguous: the sorting effect increases the average use of paid childcare if the effect from less rigorous screening dominates, and it is negative otherwise.

\footnotetext{
${ }^{16}$ Lazear (1990) shows theoretically that inefficiency can be offset by specifying employment contracts to have an ex ante payment from the worker to the employer.

${ }^{17}$ It could also be the case that workers who do not use paid parental leave or temporary parental leave move to small firms after the reform if they believe that the reform leads to higher wages or if they don't like to work with parents and they believe that the share of working parents will go down.
} 
A softer employment protection makes a worker's productivity and continued employment more closely linked and can thereby affect the worker's absence behavior. A lower protection means that an absence period is more likely to terminate an employment - a greater cost of an absence period. Costs associated with absence can vary with the job characteristics: if the job involves complementarities between coworkers, the absence of one worker affects other workers' productivity; unexpected absence can be extra costly when a substitute is hard to find at short notice. The type of absence sends different signals to employers, paid childcare can reveal how a worker values an employment relation relative to the family while sickness absence reveals information on an individual's health status. The signaling cost of absence may vary with social norms. Albrecht et al (1999) present empirical results that can be interpreted as if parental leave by fathers' signals a lack of career commitment while parental leave by mothers contains no such information. Bygren and Duvander (2006) find that workplace norms affect parents' use of parental leave, especially among fathers, and a key finding is that men at workplaces where men tend not to use parental leave are less likely to use parental leave themselves.

\subsection{The indirect effect}

In a collective family model, the intra-household distribution of parental childcare depends on parents' relative bargaining power (see, for instance, Blundell, Chiappori, and Meghir (2005)). Distributional factors can change parents' relative bargaining power and are defined as factors that influence the decision process within a household without having an effect on parents' preferences or their joint consumption set (Browning and Chiappori (1998)). Examples of distribution factors are legislations and relative income changes. Parys and Schwerhoff (2010) use a collective family model to analyze how parental leave is divided within a household and show that a distribution factor that increases one of the partner's bargaining power leads to shorter parental leave by that partner and longer leave by the other partner if the level of parental leave is kept constant. ${ }^{18}$

The cost, in terms of dismissal risk, for being absent depends on the level of employment protection. A worker with strong employment protection is less likely to be dismissed and miss out on future income if absent in comparison to a worker with weak employment protection. Hence, parents' relative cost of providing paid childcare

\footnotetext{
${ }^{18}$ Another approach is found in Amilon (2007) where a non-cooperative Stackelberg model is used to explain spouses' use of temporary parental leave.
} 
depends on their relative employment protection. The reform of the seniority rule can thereby be viewed as a distribution factor potentially altering the intra-household distribution of parental childcare in families with treatment variation. ${ }^{19}$ In these families, the reform increased the cost for providing childcare for the treated partner, but had no direct impact on the cost for the untreated partner. A reallocation of care from the treated partner to the untreated partner allows the treated partner to react to the softer employment protection without causing an external effect on the child. A redistribution of care is particularly motivated in economic terms if the treated partner is the main income provider, since then, the expected cost for being absent is relatively higher for the family compared to when the treated partner is the secondary income provider.

\section{$4 \quad$ Data description and empirical strategy}

\subsection{Data description}

I base the analysis on linked employer-employee data from Statistics Sweden that holds information on all registered employees in Sweden. I analyze a yearly balanced panel containing 291,063 individuals between 20 and 65 years of age employed in firms with two to 50 employees between the years 1997 and 2003. The data contain information on an individual's sex, age, childbearing, whether being parent of a child under eight, industry code of the firm, and county. Monthly information on firm size, in terms of the number of employees, is collected from the Swedish employment register (Anställningsregistret). To provide a measure that reflects the whole year, I define the size of a firm as its average monthly size during the year. A person who is employed by more than one firm during a year is matched to the firm that the highest annual wage earning came from.

I then add individual information on parental leave and temporary parental leave from the Swedish National Insurance Board. These data include start and end dates for all spells in Sweden during the given period. I measure parental leave and temporary parental leave in two ways: i) the yearly incidence defined as the probability of having at least one paid spell during a given year, and ii) the total days of paid leave for spells started in a given year.

\footnotetext{
${ }^{19}$ Considering the reform as a distribution factor presupposes that the reform did not affect wages in small firms.
} 
The use of paid parental leave may underestimate the reform effect for total days of parental leave. Uncompensated parental leave can be used to prolong the leave beyond the given days of benefits. In such cases, paid parental leave underreports the actual number of days on parental leave. If the reform implied a reduction of uncompensated parental leave rather than compensated parental leave, the use of paid parental leave underestimates the total effect. ${ }^{20}$ The estimate of the reform effect for fathers' parental leave can be biased if the earmarked daddy days that were introduced in 2002 affected fathers in the treatment group and the control group differently. But, it is common for fathers to take parental leave during regular vacation - a pattern that should not be altered by a lower employment protection. If anything, I expect the bias from the earmarked daddy days to occur in 2003 at the earliest since fathers do, on average, start their parental leave when the child is older than one year (Swedish National Insurance Board (2004)). ${ }^{21}$

\subsection{Empirical strategy}

In my empirical strategy, I utilize the exemption in the seniority rule introduced in 2001 to examine if employment protection influences working parents' provision of childcare. The reform created within country variation in the level of employment protection as it was targeted towards firms with two to ten employees. Thus, I can use a difference-in-difference estimator to examine if a softer employment protection affects parents’ willingness to provide childcare. The regression version of the difference-indifference estimator has the following form:

$$
Y_{i g t}=\alpha+\lambda_{t}+\beta X_{i t}+\pi D_{g t}+\delta\left(D_{g t} \times \text { Post }_{t}\right)+\varepsilon_{i g t}
$$

where $Y_{i g t}$ is the average outcome for individual $i$ in group $g$ at time $t, \lambda_{t}$ represents time effects, $X_{i t}$ includes individual covariates, $D_{g t}$ indicates whether a person belongs to the treatment group at time $t$, Post $_{t}$ takes the value of one for periods from 2001 and onwards, and zero otherwise. The difference-in-difference estimator is represented by the interaction term $D_{g t} \times$ Post $_{t}$ and $\delta$ captures the average treatment effect under the

\footnotetext{
${ }^{20}$ The correlation between paid days of parental leave and the actual number of days on parental leave is stronger for fathers. The estimate of the reform effect on total days of parental leave might therefore be more biased for mothers (Swedish National Insurance Board (2004)). For temporary parental leave, there are no reasons for not drawing full benefits while caring for the sick child.

${ }^{21}$ I find no evidence that the daddy month reform effect vary between small and large firms, i.e. with the level of employment protection. A potential explanation is that leave can be taken during vacation in order to not displease an employer. By doing that, a worker gets the same number of days off from work while receiving the unused vacation days in economic terms on top of the economic compensation from the parental leave insurance.
} 
assumption that the trends in average childcare would have been the same in treated and control firms if the reform had not happened.

The treatment group consists of individuals employed in firms with two to ten employees and the control group consists of individuals employed in firms with eleven to 50 employees. ${ }^{22}$ The upper limit of the control group is based on two arguments: i) the pre-reform trend for temporary parental leave and parental leave is similar in the control group and the treatment group, and (ii) when I use a balanced panel I implicitly assume that the reform had the same effect on the probability of staying in the panel for employees in the treatment and the control group. ${ }^{23}$ A high upper limit of the control group allows individuals to switch employers or be employed in firms that grow over time without being excluded from the sample - an important feature for the behavioral analysis.

Treatment is a function of firm size and it is consequently endogenous. Workers can seek employment in treated or untreated firms and firms can adjust the size of their workforce by hiring or separating workers. The composition of the workforce in small firms may therefore have changed via a sorting effect when the employment protection was relaxed. $^{24}$ But in line with von Below and Skogman Thoursie (2010) I find no evidence of firms adjusting the size of their workforce as a reaction to the reform when I compare the firm size distribution before and after the reform, see Figure A1 in Appendix. ${ }^{25}$

The difference-in-difference estimator in equation (1) captures both a behavioral effect and a sorting effect. A sorting effect is interesting on its own but will bias the estimate of the behavioral effect. Separating the two effects is difficult, but with individual data and assuming that the effects are additive separable and that the treatment effect is constant, the behavioral effect is isolated by an instrumental variable approach, as done by Lindbeck et al (2006). The sorting effect is then the difference between the total effect and the behavioral effect. Treatment status in the spring of 2000, a period when the reform had not yet become public information, is arguably a valid instrument for treatment status in later years. The instrument is correlated with

\footnotetext{
${ }^{22}$ The treatment group is also referred to as small firms and the control group as large firms.

${ }^{23}$ For the repeated cross-sectional sample, the difference-in-difference estimate for the probability of being in the sample the following year is insignificant (the estimate is -0.0009 with a standard error of 0.0007 ) when comparing the period before and after the reform.

${ }^{24}$ The probability for a small firm to enter or exit from the market was not changed by the reform in 2001 (von Below and Skogman Thoursie (2010)).

${ }^{25}$ The overall results using firm aggregated data are similar to the results using individual data, see Table A1 in Appendix.
} 
later treatment status but uncorrelated with later outcomes caused by the reform since an individual in the spring of 2000 did not know if the reform was to be implemented or not. ${ }^{26}$ With individual data the use of the past treatment status deals with sorting of workers if firms alter their workforce or if workers change employers. The instrumental version of the difference-in-difference estimator identifies the behavioral effect for workers employed in small firms in the spring of $2000 .^{27}$

Table 1 presents summary statistics for the treatment group and the control group for the pre-period of 1997 to 2000 and for the post-period of 2001 to 2003. The balanced panel implies that I examine well-established workers mainly in the private sector since the focus is on small firms and is reflected in the low share of females. In the preperiod, the average age, the share of females and average childbearing are similar in the two groups, while the use of parental leave and temporary parental leave is higher in the control group. Comparing the pre-period and the post-period, the share of employees with small children and employees who are childbearing becomes relative smaller in the treatment group while the average age of an employee in the treatment group increases.

\footnotetext{
${ }^{26}$ Recall that the reform was an outcome of an unexpected collaboration between the Green Party and the nonsocialist parties and was publicly discussed during the spring of 2000. The instrumental variable model will estimate a local average treatment effect. Treatment status in the spring of 2000 is arguably a valid instrument as the reform became public information in mid 2000 and that matching on the labor market is not instantaneous.

27 The sorting effect can be identified under the assumptions that the sorting and behavioral effects are additive separable and that the treatment effect is constant. In that case, the sorting effect is the difference between the overall effect and the behavioral effect.
} 
Table 1 Summary statistics - average values for employees in treated and control firms before and after the reform

\begin{tabular}{|c|c|c|c|c|c|}
\hline & \multicolumn{2}{|c|}{ Treated firms } & \multicolumn{2}{|c|}{ Control firms } & \multirow[b]{2}{*}{ DiD } \\
\hline & After & Before & After & Before & \\
\hline Age & $\begin{array}{c}45.4630 \\
(10.5585)\end{array}$ & $\begin{array}{c}41.6898 \\
(10.5802)\end{array}$ & $\begin{array}{c}44.5989 \\
(10.6050)\end{array}$ & $\begin{array}{c}41.2660 \\
(10.6507)\end{array}$ & $\begin{array}{c}0.4402 * * * \\
(0.0323)\end{array}$ \\
\hline Female & $\begin{array}{c}0.3030 \\
(0.4595)\end{array}$ & $\begin{array}{c}0.3015 \\
(0.4589)\end{array}$ & $\begin{array}{c}0.3036 \\
(0.4598)\end{array}$ & $\begin{array}{c}0.3048 \\
(0.4603)\end{array}$ & $\begin{array}{l}0.0026 * \\
(0.0016)\end{array}$ \\
\hline Parents with child aged $<12$ & $\begin{array}{c}0.3166 \\
(0.4652)\end{array}$ & $\begin{array}{c}0.3518 \\
(0.4775)\end{array}$ & $\begin{array}{c}0.3308 \\
(0.4705)\end{array}$ & $\begin{array}{c}0.3499 \\
(0.4769)\end{array}$ & $\begin{array}{c}-0.0162 * * * \\
(0.0016)\end{array}$ \\
\hline Parents & $\begin{array}{c}0.7905 \\
(0.4070)\end{array}$ & $\begin{array}{c}0.7383 \\
(0.4396)\end{array}$ & $\begin{array}{c}0.7697 \\
(0.4210)\end{array}$ & $\begin{array}{c}0.7159 \\
(0.4510)\end{array}$ & $\begin{array}{l}-0.0016 \\
(0.0013)\end{array}$ \\
\hline Parental leave: incidence & $\begin{array}{c}0.0822 \\
(0.2747)\end{array}$ & $\begin{array}{c}0.0653 \\
(0.2471)\end{array}$ & $\begin{array}{c}0.1009 \\
(0.3012)\end{array}$ & $\begin{array}{c}0.0778 \\
(0.2679)\end{array}$ & $\begin{array}{c}-0.0062 * * * \\
(0.0009)\end{array}$ \\
\hline Parental leave: total days & $\begin{array}{c}7.6503 \\
(49.4719)\end{array}$ & $\begin{array}{c}6.9652 \\
(49.2744)\end{array}$ & $\begin{array}{c}9.2475 \\
(54.2641)\end{array}$ & $\begin{array}{c}7.8496 \\
(51.8436)\end{array}$ & $\begin{array}{c}-0.7128 * * * \\
(0.1536)\end{array}$ \\
\hline Temporary parental leave: incidence & $\begin{array}{c}0.1383 \\
(0.3452)\end{array}$ & $\begin{array}{c}0.1341 \\
(0.3407)\end{array}$ & $\begin{array}{c}0.1730 \\
(0.3783)\end{array}$ & $\begin{array}{c}0.1641 \\
(0.3703)\end{array}$ & $\begin{array}{c}-0.0047^{* * *} \\
(0.001)\end{array}$ \\
\hline Temporary parental leave: total days & $\begin{array}{c}0.8958 \\
(3.6238)\end{array}$ & $\begin{array}{c}0.8429 \\
(3.4403)\end{array}$ & $\begin{array}{c}1.0910 \\
(3.3759)\end{array}$ & $\begin{array}{c}0.9921 \\
(3.6557)\end{array}$ & $\begin{array}{c}-0.0450 * * * \\
(0.0119)\end{array}$ \\
\hline Childbearing & $\begin{array}{c}0.0320 \\
(0.1760)\end{array}$ & $\begin{array}{c}0.0356 \\
(0.1854)\end{array}$ & $\begin{array}{c}0.0355 \\
(0.1851)\end{array}$ & $\begin{array}{c}0.0371 \\
(0.1891)\end{array}$ & $\begin{array}{c}-0.0020 * * * \\
(0.0005)\end{array}$ \\
\hline Observations & 355,999 & 508,686 & 517,190 & 655,566 & $2,037,441$ \\
\hline
\end{tabular}

Compositional changes can bias the estimate of a behavioral effect. The regression version of the difference-in-difference estimator represented by equation (1) allows me to control for observed compositional changes as long as I do not control for an outcome itself. A potential problem when analyzing parental childcare is that childbearing can change in reaction to less employment protection and the identification of a behavioral effect requires the trends in childbearing to be constant between the treatment group and the control group. The upper panel of Figure 2 plots the share of workers in the treatment group and the control group that got at least one child during a given year from 1997 to 2003. No sign of a reform effect on childbearing is seen, a conclusion that becomes more evident if I analyze yearly childbearing effects with the difference in 1997 as the base year; see the bottom panel of Figure 2. No change in 
childbearing is seen at the reform year or later, but a relative drop occurs between 1999 and 2000 in small firms. The drop is not an outcome of the 2001-reform, as it became public information in the mid 2000. But the drop can bias the estimate of the reform effect since the impact from a change in childbearing can influence parental leave and temporary parental leave for several years. I control for childbearing in 2000 in the upcoming analysis to account for the drop in childbearing between 1999 and 2000.


Figure 2 Average childbearing for employees in treated and control firms from 1997 to 2003

Notes: The figure in the upper panel displays average yearly childbearing in absolute levels. The figure in the bottom panel displays the yearly difference in childbearing between treated and control relative to the group difference in 1997. For each difference, a 95 percent confidence interval is presented. Treated refers to firms with two to ten employees and control refers to firms with eleven to 50 employees.

\section{$5 \quad$ Results}

\subsection{The direct effect}

A crude means comparison of parental leave and temporary parental leave in Table 1 provides a first indication that employment protection influences parental childcare. In the years following the softening of the employment protection, the average used days of paid parental leave decreases by 0.71 days per year and worker in small firms relative to the use in large firms. A decline by 0.71 days corresponds to a reduction by 10.2 percent compared to the pretreatment average in small firms. Temporary parental leave drops by 0.045 days on average, a relative decline by 5.3 percent. The results from 
Table 1 suggest that the incidence of parental leave and temporary parental leave declines in reaction to a softer employment protection.

To quantify the reform effect, I use a difference-in-difference estimator. A comparison of pre-reform outcomes for the treatment group and the control group is the only way of evaluating the crucial assumption of a parallel trend in the absence of treatment for the difference-in-difference estimator (Card et al (2011)). Similar trends in years prior to the reform tell that economic shocks have affected the groups similarly in the past, indicating that the control group can serve as the counterfactual trend for the treatment group also after the reform. Figure 3 plots the average use of paid parental leave in the treatment group and the control group for the period 1997 to 2003 . The yearly incidence is displayed in the top panel and total days of compensated parental leave in the bottom panel. All figures use normalized data purged on individual variation in childbearing and refer to total changes (compositional changes plus behavioral changes). Sub-figures in the right-hand column display yearly effects with a 95-percent confidence interval where the group difference in 2000 is used as the base year. ${ }^{28}$ Looking at the trends, a subtle statistically significant relative drop in the incidence and the total days of leave is seen in small firms in 2001. The new lower level is sustained for the whole post period. Looking at the pre period, the incidence and total days have similar trends in the treatment group and the control group for three years. But for 1997, the estimated group difference is statistically different from the group difference in 2000. The similar pre trends for three pre years suggest that the decline in childcare stems from a softer employment protection induced by the reform in 2001, though, the estimated year effect for 1997 indicates that any long run effects should be interpreted with care.

\footnotetext{
${ }^{28}$ Each yearly effect represents a difference-in-difference estimate for the relative difference between the treated group and the control group in a given year relative the group difference in year 2000 .
} 

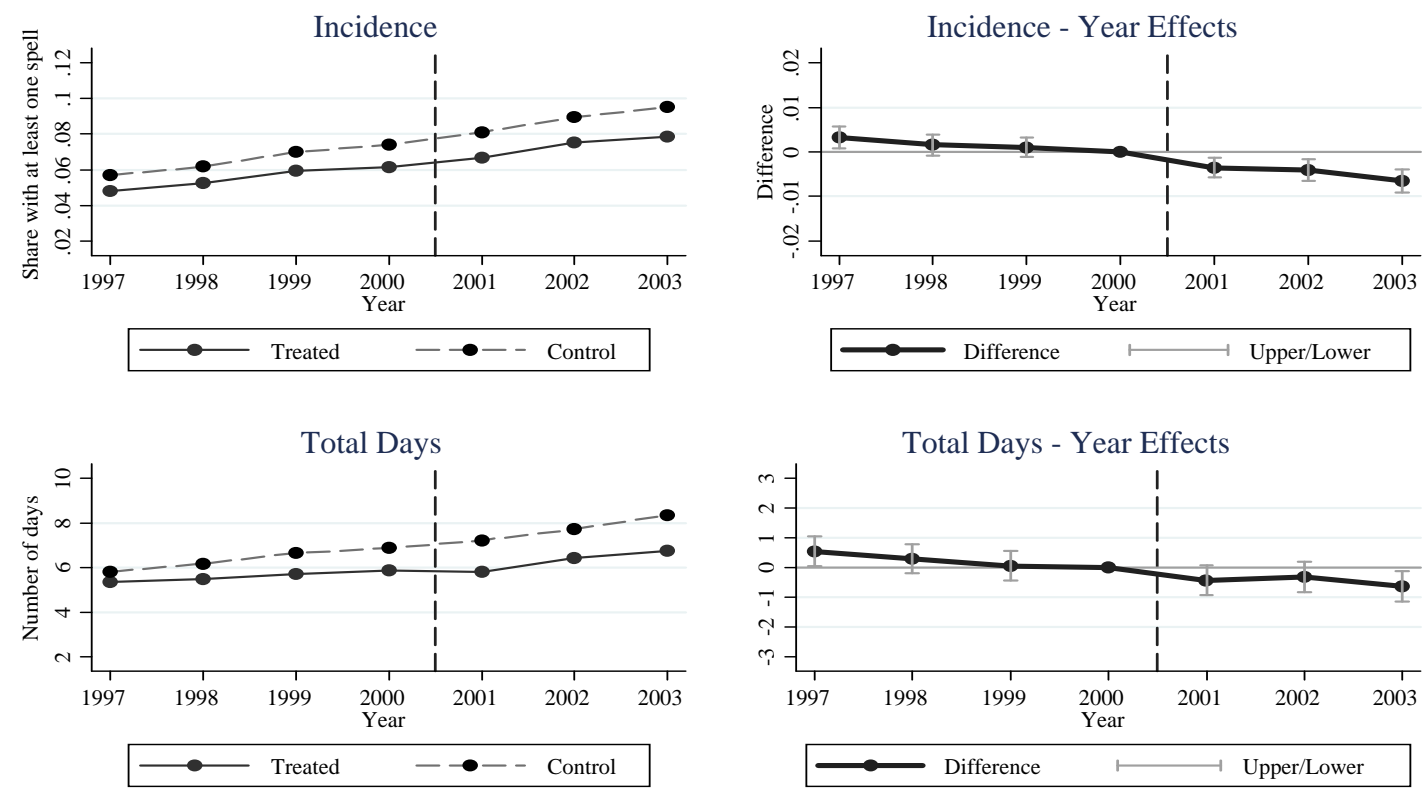

Figure 3 Average usage of parental leave in treated and control firms from 1997 to 2003

Notes: "Incidence" refers to the probability of having at least one spell in a year. "Year Effects" refers to the yearly group difference relative to the group difference in 2000 and are displayed with 95 percent confidence intervals. "Treated" refers to firms with two to ten employees and "Control" refers to firms with eleven to 50 employees.

Figure 4 displays the use of temporary parental leave for employees in small and large firms between 1997 and 2003. Once again, the groups show parallel trends before the reform, which suggests that the subsequent drop of childcare in small firms at the year of the reform stems from softer employment protection. 

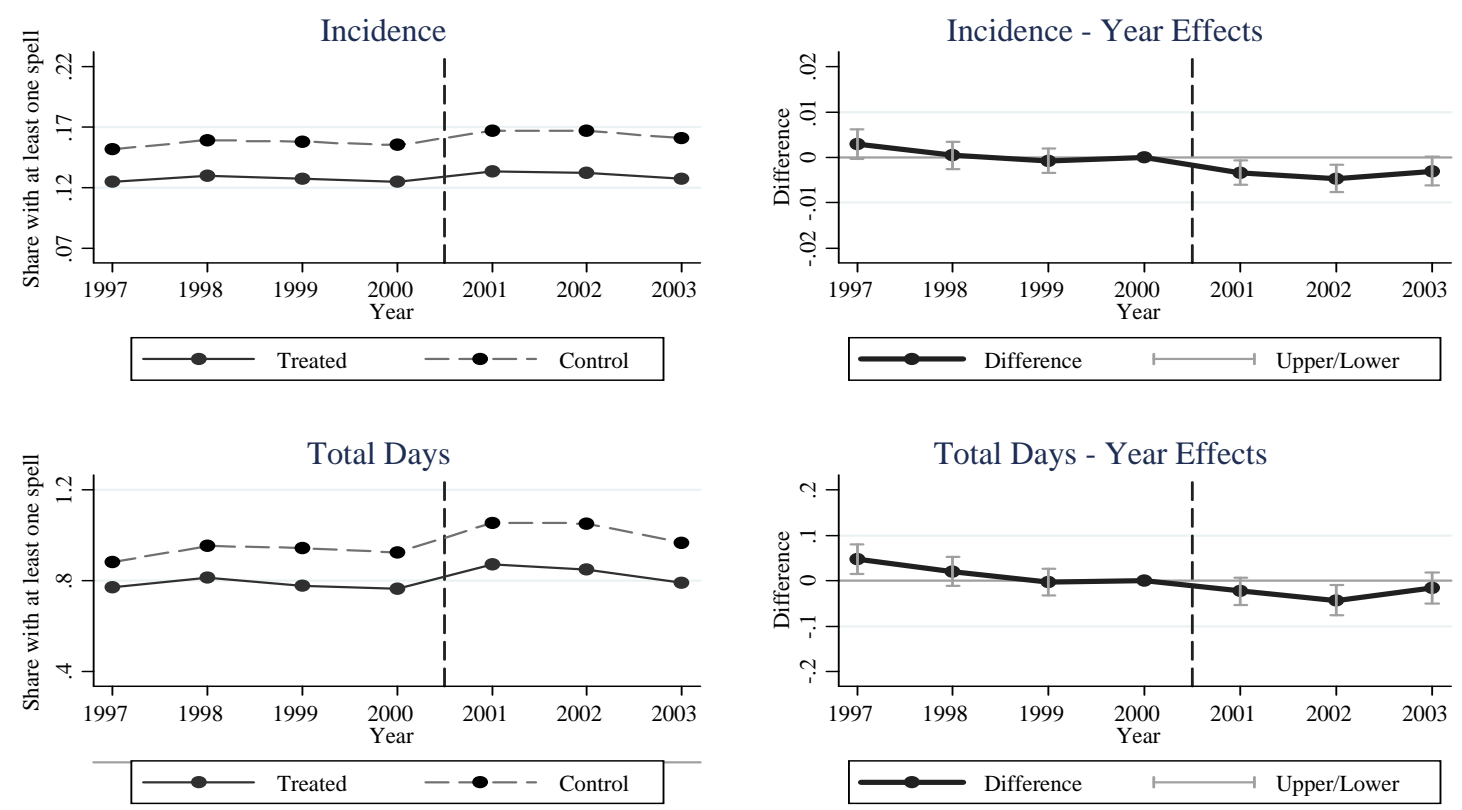

Figure 4 Average usage of temporary parental leave in treated and control firms from 1997 to 2003

Notes: "Incidence" refers to the probability of having at least one spell in a year. "Year Effects" refers to the yearly group difference relative the group difference in 2000. All differences are displayed with 95 percent confidence intervals. "Treated" refers to firms with two to ten employees and "control" refers to firms with eleven to 50 employees.

Difference-in-difference estimates for the reform effect on parental leave are displayed in Table 2. The probability of having at least one spell of parental leave in a year is estimated to decrease by 0.66 percentage points in small firms in reaction to the reform. ${ }^{29}$ The estimate of -0.66 percentage points refers to a combined sorting effect and behavioral effect and is found among both men and women. When I control for childbearing in 2000, age of workers and child age specific effects for children aged three to eight, the effect diminishes to -0.34 percentage points but is still statistically significant. For the intention-to-treat effect, the composition in the treatment and the control group is kept constant as of the spring of 2000. The intention-to-treat effect on the incidence is -0.39 percentage points. The estimate for the behavioral effect is -0.61 percentage points. The estimate for total days of parental leave indicates a decline of 0.7359 days in reaction to the softer employment protection (the decline is 1.5040 days for women and 0.4555 days for men) equivalent to a reduction of 10.6 percent as compared to the pretreatment average. The estimates decrease when I control for

\footnotetext{
${ }^{29}$ The total effect refers to a combined sorting and behavioral effect. The model controls for childbearing to account for the relative drop in childbearing in small firms in 2000.
} 
childbearing in 2000, age and child age effects: the overall effect is estimated to -0.4368 days and the estimate for the behavioral effect is -0.5928 days.

Table 2 Parental leave - average reform effects

\begin{tabular}{|c|c|c|c|c|c|c|}
\hline & \multicolumn{3}{|c|}{ Incidence } & \multicolumn{3}{|c|}{ Total days } \\
\hline & All & Women & Men & All & Women & Men \\
\hline & $(1)$ & $(2)$ & (3) & (4) & (5) & (6) \\
\hline Total effect & $\begin{array}{c}-0.0066^{* * *} \\
(0.0009)\end{array}$ & $\begin{array}{c}-0.0081^{* * *} \\
(0.0015)\end{array}$ & $\begin{array}{c}-0.0060 * * * \\
(0.0011)\end{array}$ & $\begin{array}{c}-0.7359 * * * \\
(0.1536)\end{array}$ & $\begin{array}{c}-1.5040 * * * \\
(0.4429)\end{array}$ & $\begin{array}{c}-0.4555^{* * *} \\
(0.0957)\end{array}$ \\
\hline $\begin{array}{l}\text { Total effect } \\
\text { controlling for } \\
\text { childbearing before } \\
2001\end{array}$ & $\begin{array}{c}-0.0061^{* * *} \\
(0.0009)\end{array}$ & $\begin{array}{c}-0.0074 * * * \\
(0.0015)\end{array}$ & $\begin{array}{c}-0.0057 * * * \\
(0.0010)\end{array}$ & $\begin{array}{c}-0.6801 * * * \\
(0.1527)\end{array}$ & $\begin{array}{c}-1.2824 * * * \\
(0.4372)\end{array}$ & $\begin{array}{c}-0.4386^{* * * *} \\
(0.0952)\end{array}$ \\
\hline $\begin{array}{l}\text { Total effect } \\
\text { controlling for } \\
\text { childbearing in } 2000 \\
\text { and age }\end{array}$ & $\begin{array}{c}-0.0042 * * * \\
(0.0009)\end{array}$ & $\begin{array}{c}-0.0045^{* * *} \\
(0.0015)\end{array}$ & $\begin{array}{c}-0.0042^{* * *} \\
(0.0010)\end{array}$ & $\begin{array}{c}-0.4644 * * * \\
(0.1511)\end{array}$ & $\begin{array}{l}-0.6209 \\
(0.4275)\end{array}$ & $\begin{array}{c}0.3654 * * * \\
(0.0948)\end{array}$ \\
\hline $\begin{array}{l}\text { Total effect } \\
\text { controlling for } \\
\text { childbearing in 2000, } \\
\text { age and child age } \\
\text { specific effects }\end{array}$ & $\begin{array}{c}-0.0034^{* * *} \\
(0.0008)\end{array}$ & $\begin{array}{c}-0.0040 * * * \\
(0.0014)\end{array}$ & $\begin{array}{c}-0.0031^{* * *} \\
(0.0010)\end{array}$ & $\begin{array}{c}-0.4368 * * * \\
(0.1515)\end{array}$ & $\begin{array}{c}-0.6162 \\
(0.4300)\end{array}$ & $\begin{array}{c}-0.3295^{* * * *} \\
(0.0944)\end{array}$ \\
\hline $\begin{array}{l}\text { ITT controlling for } \\
\text { childbearing in } 2000 \text {, } \\
\text { age and child age } \\
\text { specific effects }\end{array}$ & $\begin{array}{c}-0.0039 * * * \\
(0.0008)\end{array}$ & $\begin{array}{c}-0.0056 * * * \\
(0.0015)\end{array}$ & $\begin{array}{c}-0.0031^{* * *} \\
(0.0010)\end{array}$ & $\begin{array}{c}-0.5117 * * * \\
(0.1511)\end{array}$ & $\begin{array}{c}-1.0387 * * \\
(0.4347)\end{array}$ & $\begin{array}{c}-0.2499 * * * \\
(0.0951)\end{array}$ \\
\hline $\begin{array}{l}\text { IV controlling for } \\
\text { childbearing in } 2000 \text {, } \\
\text { age and child age } \\
\text { specific effects }\end{array}$ & $\begin{array}{c}-0.0061^{* * *} \\
(0.0011)\end{array}$ & $\begin{array}{c}-0.0081 * * * \\
(0.0019)\end{array}$ & $\begin{array}{c}-0.0052 * * * \\
(0.0013)\end{array}$ & $\begin{array}{c}-0.5928 * * * \\
(0.1761)\end{array}$ & $\begin{array}{c}-0.6811^{* *} \\
(0.3306)\end{array}$ & $\begin{array}{c}-0.3381^{* * *} \\
(0.1242)\end{array}$ \\
\hline Pretreatment average & 0.0653 & 0.0701 & 0.0633 & 6.9652 & 16.0168 & 3.0580 \\
\hline Observations & $2,037,441$ & 618,079 & $1,419,362$ & $2,087,127$ & 632,401 & $1,454,726$ \\
\hline
\end{tabular}

Table 3 presents reform effects for temporary parental leave. Once more, I find that parental childcare decreases in small firms after the relaxation of the employment protection: an average worker in a small firm is estimated to be 0.47 percentage points less likely to have a case of temporary parental leave during a given year after the reform and the total days of temporary parental leave are estimated to decrease by 0.0462 days (a decline of 5.5 percent compared to the pretreatment average). When I control for age of the parent and of the child neither women nor men are estimated to 
decrease their use of temporary parental leave. The drop in temporary parental leave seems thereby driven by a sorting effect. But the behavioral effect is estimated to be negative suggesting that sorting cannot explain everything, at least for employees in small firms in the spring of $2000 .^{30}$

Table 3 Temporary parental leave - average reform effects

\begin{tabular}{|c|c|c|c|c|c|c|}
\hline & \multicolumn{3}{|c|}{ Incidence } & \multicolumn{3}{|c|}{ Total days } \\
\hline & All & Women & Men & All & Women & Men \\
\hline & $(1)$ & $(2)$ & (3) & (4) & (5) & $(6)$ \\
\hline Total effect & $\begin{array}{c}-0.0047^{* * *} \\
(0.0012)\end{array}$ & $\begin{array}{c}-0.0089 * * * \\
(0.0022)\end{array}$ & $\begin{array}{c}-0.0031^{* *} \\
(0.0013)\end{array}$ & $\begin{array}{c}-0.0462^{* * *} \\
(0.0119)\end{array}$ & $\begin{array}{c}-0.1092 * * * \\
(0.0257)\end{array}$ & $\begin{array}{c}-0.0219 * \\
(0.0126)\end{array}$ \\
\hline $\begin{array}{l}\text { Total effect } \\
\text { controlling for } \\
\text { childbearing in } 2000\end{array}$ & $\begin{array}{c}-0.0044^{* * *} \\
(0.0011)\end{array}$ & $\begin{array}{c}-0.0084^{* * *} \\
(0.0022)\end{array}$ & $\begin{array}{c}-0.0029 * * \\
(0.0013)\end{array}$ & $\begin{array}{c}-0.0437 * * * \\
(0.0118)\end{array}$ & $\begin{array}{c}-0.1043^{* * *} \\
(0.0258)\end{array}$ & $\begin{array}{c}-0.0201 \\
(0.0125)\end{array}$ \\
\hline $\begin{array}{l}\text { Total effect } \\
\text { controlling for } \\
\text { childbearing in } 2000 \\
\text { and age }\end{array}$ & $\begin{array}{l}-0.0015 \\
(0.0001)\end{array}$ & $\begin{array}{c}-0.0032 \\
(0.0021)\end{array}$ & $\begin{array}{l}-0.0008 \\
(0.0013)\end{array}$ & $\begin{array}{c}-0.0241^{* *} \\
(0.0117)\end{array}$ & $\begin{array}{c}-0.0627^{* *} \\
(0.0251)\end{array}$ & $\begin{array}{c}-0.0077 \\
(0.0124)\end{array}$ \\
\hline $\begin{array}{l}\text { Total effect } \\
\text { controlling for } \\
\text { childbearing in 2000, } \\
\text { age and child age } \\
\text { specific effects }\end{array}$ & $\begin{array}{c}0.0013 \\
(0.0010)\end{array}$ & $\begin{array}{c}0.0011 \\
(0.0017)\end{array}$ & $\begin{array}{c}0.0018 \\
(0.0011)\end{array}$ & $\begin{array}{l}-0.0059 \\
(0.0110)\end{array}$ & $\begin{array}{l}-0.0334 \\
(0.0227)\end{array}$ & $\begin{array}{c}0.0063 \\
(0.0119)\end{array}$ \\
\hline $\begin{array}{l}\text { ITT controlling for } \\
\text { childbearing in 2000, } \\
\text { age and child age } \\
\text { specific effects }\end{array}$ & $\begin{array}{l}-0.0010 \\
(0.0009)\end{array}$ & $\begin{array}{l}-0.0007 \\
(0.0017)\end{array}$ & $\begin{array}{l}-0.0007 \\
(0.0011)\end{array}$ & $\begin{array}{c}-0.0332^{* * *} \\
(0.0109)\end{array}$ & $\begin{array}{c}-0.0586 * * * \\
(0.0225)\end{array}$ & $\begin{array}{c}-0.0174 \\
(0.0120)\end{array}$ \\
\hline $\begin{array}{l}\text { IV controlling for } \\
\text { childbearing in } 2000 \text {, } \\
\text { age and child age } \\
\text { specific effects }\end{array}$ & $\begin{array}{c}-0.0040 * * * \\
(0.0013)\end{array}$ & $\begin{array}{l}-0.0032 \\
(0.0022)\end{array}$ & $\begin{array}{c}-0.0038 * * \\
(0.0015)\end{array}$ & $\begin{array}{c}-0.0562 * * * \\
(0.0145)\end{array}$ & $\begin{array}{c}-0.0878 * * * \\
(0.0296)\end{array}$ & $\begin{array}{c}-0.0353^{* *} \\
(0.0160)\end{array}$ \\
\hline Pretreatment average & 0.1341 & 0.1709 & 0.1181 & 0.8429 & 1.3178 & 0.6378 \\
\hline Observations & $2,037,441$ & 618,079 & $1,419,362$ & $2,037,441$ & 618,079 & $1,419,362$ \\
\hline
\end{tabular}

\subsection{The indirect effect}

Do parents redistribute leave within the family if one parent gets a lower employment protection? I try to answer this question by examining if childcare by spouses who

\footnotetext{
${ }^{30}$ The overall results are robust when I run the model using group-year aggregated data to account for intra-class correlation, see Donald and Lang (2007).
} 
themselves were unaffected by the reform in 2001 changes if their partner was affected by the reform. If spousal childcare increases in reaction to the partner's higher risk of being dismissed, it indicates a redistribution of leave since the spouse was only affected by the reform via the directly affected partner. Partners are not linked in the data so I define a couple as two individuals that live in the same household, are registered as cohabiting or married and with an age difference of at most 15 years. Conditioning on within-couple variation in treatment reduces the sample size substantially. I therefore create an unbalanced panel with individuals that were at least employed in a firm with 11 to 50 employees in the spring of 2000 to estimate the behavioral effect. I then define the treatment group as spouses who were directly unaffected by the reform but who lived with a partner in 2001 who was affected by the reform. I label individuals in the treatment group as indirectly treated spouses. The control group contains partners in couples where both were unaffected by the reform in 2001. The sample contains 218,879 observations.

Table 4 presents behavioral reform effects for indirectly treated spouses. I interpret a positive effect for an indirectly treated spouse as redistribution of leave. For indirectly treated, only men are estimated to react to their partner's softer employment protection. An indirect effect is especially pronounced for temporary parental leave. Spouses' relative bargaining power within the family can be reflected by their relative income. In that case, the preferences of the main income provider should be relatively more important for the decision to redistribute leave or not. I examine if the redistribution effect differs if the indirectly affected partner is the main or the secondary income provider in a couple. The results are displayed in Table $4 .{ }^{31} \mathrm{~A}$ redistribution of paid childcare occurs only when the main income provider is an indirectly affected man: the total days of temporary parental leave are estimated to increase by more than 17.4 percent (0.2163 days) among high income men and the probability of having at least one spell of temporary parental leave per year increase by 17.7 percent (4.37 percentage points). That indirectly treated men with a relative high income react to their partners' softer employment protection can be a sign of that a flexible job makes it easier to take temporary parental leave while still work partly at home and having a high income is associated with a more flexible job.

\footnotetext{
${ }^{31}$ The average values for parental childcare in the post period show that men that are main income providers use more leave compared to men that are secondary income providers and is consistent with Duvander and Sundström (2002) who also show that fathers' educational level increases the use of parental leave when earnings are held constant.
} 
In couples where both partners are treated, reallocation of leave to an unaffected spouse is not possible. Still, a reallocation can be economically motivated if the expected cost from a higher unemployment risk differs between partners. Table 5 displays how individuals in couples where both partners got a weaker employment protection reacted, separately. The control group consists of partners in couples where neither got treated. Once again, I use an unbalanced sample where all individuals are at least present in the spring of 2000. The sample is divided into relative high and low income providers within couples and the cross diagonals for each outcome reflect the average total reaction for couples. For parental leave, a decline is found for men unconditional of their relative income status but for women only total days of parental leave drops (by 0.65 days). I fail to find support of any redistribution effect. Instead, the estimates suggest that children to parents who both received a softer employment protection spend less parental leave days with their parents. For temporary parental leave, only low-income men are estimated to reduce the total days of leave, consistent with the idea that high income men have more flexible jobs. 
Table 4 Redistribution effects - reform effects for indirectly treated partners, overall and by relative income status

\begin{tabular}{|c|c|c|c|c|c|c|c|c|}
\hline & \multicolumn{4}{|c|}{ Parental leave } & \multicolumn{4}{|c|}{ Temporary parental leave } \\
\hline & \multicolumn{2}{|c|}{ Incidence } & \multicolumn{2}{|c|}{ Total days } & \multicolumn{2}{|c|}{ Incidence } & \multicolumn{2}{|c|}{ Total days } \\
\hline & Women & Men & Women & Men & Women & Men & Women & Men \\
\hline & (1) & $(2)$ & (3) & (4) & (5) & (6) & (7) & (8) \\
\hline Indirect treated & $\begin{array}{c}0.0099 \\
(0.0064)\end{array}$ & $\begin{array}{l}0.0122 * \\
(0.0068)\end{array}$ & $\begin{array}{c}2.6703 \\
(2.0438)\end{array}$ & $\begin{array}{c}0.8652 \\
(0.6958)\end{array}$ & $\begin{array}{c}0.0086 \\
(0.0072)\end{array}$ & $\begin{array}{c}0.0374 * * * \\
(0.0073)\end{array}$ & $\begin{array}{c}0.0081 \\
(0.1017)\end{array}$ & $\begin{array}{c}0.1642 * * \\
(0.0788)\end{array}$ \\
\hline Pretreatment average & 0.1684 & 0.1423 & 40.0361 & 6.8827 & 0.3311 & 0.2381 & 2.4942 & 1.2348 \\
\hline Observations & 111,308 & 107,571 & 111,308 & 107,571 & 111,308 & 107,571 & 111,308 & 107,571 \\
\hline Indirectly treated with high income & $\begin{array}{c}0.0079 \\
(0.0103)\end{array}$ & $\begin{array}{c}0.0167 * * \\
(0.0077)\end{array}$ & $\begin{array}{c}3.2741 \\
(2.4268)\end{array}$ & $\begin{array}{c}1.0450 \\
(0.7880)\end{array}$ & $\begin{array}{c}-0.0004 \\
(0.0132)\end{array}$ & $\begin{array}{c}0.0437 * * * \\
(0.0081)\end{array}$ & $\begin{array}{c}0.0539 \\
(0.1759)\end{array}$ & $\begin{array}{c}0.2163 * * \\
(0.0850)\end{array}$ \\
\hline Pretreatment average & 0.0931 & 0.1533 & 14.6299 & 7.2969 & 0.2838 & 0.2471 & 2.0166 & 1.2418 \\
\hline Observations & 25,949 & 89,994 & 25,949 & 89,994 & 25,949 & 89,994 & 25,949 & 89,994 \\
\hline Indirectly treated with low income & $\begin{array}{c}0.0102 \\
(0.0077)\end{array}$ & $\begin{array}{l}-0.0108 \\
(0.0122)\end{array}$ & $\begin{array}{c}2.1753 \\
(2.5719)\end{array}$ & $\begin{array}{c}-0.0489 \\
(1.4169)\end{array}$ & $\begin{array}{c}0.0125 \\
(0.0085)\end{array}$ & $\begin{array}{c}0.0082 \\
(0.0161)\end{array}$ & $\begin{array}{c}0.0020 \\
(0.1213)\end{array}$ & $\begin{array}{l}-0.0835 \\
(0.2033)\end{array}$ \\
\hline Pretreatment average & 0.1952 & 0.0817 & 49.0462 & 4.6208 & 0.3479 & 0.1890 & 2.6635 & 1.1965 \\
\hline Observations & 85,359 & 17,627 & 85,359 & 17,627 & 85,359 & 17,627 & 85,359 & 17,627 \\
\hline
\end{tabular}


Table 5 Reform effects for partners in couples where both partners are treated - overall and by relative income status

\begin{tabular}{|c|c|c|c|c|c|c|c|c|}
\hline & \multicolumn{4}{|c|}{ Parental leave } & \multicolumn{4}{|c|}{ Temporary parental leave } \\
\hline & \multicolumn{2}{|c|}{ Incidence } & \multicolumn{2}{|c|}{ Total days } & \multicolumn{2}{|c|}{ Incidence } & \multicolumn{2}{|c|}{ Total days } \\
\hline & Women & Men & Women & Men & Women & Men & Women & Men \\
\hline & (1) & (2) & (3) & (4) & (5) & (6) & (7) & (8) \\
\hline Both treated & $\begin{array}{c}-0.0008 \\
(0.0031)\end{array}$ & $\begin{array}{c}-0.0139 * * * \\
(0.0030)\end{array}$ & $\begin{array}{c}1.3389 \\
(0.9889)\end{array}$ & $\begin{array}{c}-1.0748^{* * *} \\
(0.3324)\end{array}$ & $\begin{array}{l}-0.0067^{*} \\
(0.0040)\end{array}$ & $\begin{array}{l}-0.0065^{*} \\
(0.0034)\end{array}$ & $\begin{array}{l}-0.0892 \\
(0.0606)\end{array}$ & $\begin{array}{l}-0.0698 * \\
(0.0364)\end{array}$ \\
\hline Pretreatment average & 0.0749 & 0.0506 & 19.0649 & 3.4085 & 0.1620 & 0.0753 & 1.5145 & 0.4390 \\
\hline Observations & 173,230 & 173,230 & 173,230 & 173,230 & 173,230 & 173,230 & 173,230 & 173,230 \\
\hline High income partner & $\begin{array}{c}-0.0055 \\
(0.0049)\end{array}$ & $\begin{array}{c}-0.0206 * * * \\
(0.0034)\end{array}$ & $\begin{array}{c}-0.6515^{* * *} \\
(1.2017)\end{array}$ & $\begin{array}{c}-1.0787 * * * \\
(0.3727)\end{array}$ & $\begin{array}{c}-0.0014 \\
(0.0075)\end{array}$ & $\begin{array}{l}-0.0047 \\
(0.0038)\end{array}$ & $\begin{array}{c}-0.0395 \\
(0.1029)\end{array}$ & $\begin{array}{l}-0.0469 \\
(0.0408)\end{array}$ \\
\hline Pretreatment average & 0.0323 & 0.0548 & 6.1990 & 3.6206 & 0.1181 & 0.0774 & 1.1358 & 0.4483 \\
\hline Observations & 41,059 & 142,684 & 41,059 & 142,684 & 41,059 & 142,684 & 41,059 & 142,684 \\
\hline Low income partner & $\begin{array}{c}-0.0008 \\
(0.0038)\end{array}$ & $\begin{array}{c}-0.0149 * * * \\
(0.0058)\end{array}$ & $\begin{array}{c}1.2177 \\
(1.2242)\end{array}$ & $\begin{array}{l}-1.0910^{*} \\
(0.7082)\end{array}$ & $\begin{array}{l}-0.0076 \\
(0.0048)\end{array}$ & $\begin{array}{c}-0.0159 * * \\
(0.0077)\end{array}$ & $\begin{array}{c}-0.0961 \\
(0.0733)\end{array}$ & $\begin{array}{c}-0.1839 * * \\
(0.0779)\end{array}$ \\
\hline Pretreatment average & 0.0903 & 0.0308 & 23.6915 & 2.4287 & 0.1778 & 0.0656 & 1.6506 & 0.3961 \\
\hline Observations & 132,171 & 30,546 & 132,171 & 30,546 & 132,171 & 30,546 & 132,171 & 30,546 \\
\hline
\end{tabular}

Notes: Each estimate represents a separate IV-model. ***,**,* denote statistical significance at the 1,5 and 10 percent levels, respectively. Standard errors cluster at the firm level. All models control for age, childbearing in 2000 and child age specific effects (zero to eight for parental leave and zero to twelve for temporary parental leave)

A person is defined as the high-income partner if the yearly wage earnings are higher than the other partner's yearly wage earnings. 
All in all, I find some evidence that the distribution of parental childcare within the family depends on parents' relative employment protection. An interpretation is that parental childcare decisions are, at least to some extent, taken in collaboration within the family and are partially based on indirectly expected economic costs (as the reform only altered indirect expected costs from absence). The results also highlight that the dual earner family can function as a social safety net by reallocating parental childcare: a negative reform effect on the child was partially absorbed by reallocating childcare from an affected parent to an unaffected parent.

\subsection{Robustness and further analysis}

If a firm wants to reduce its workforce with one worker, the share of eligible workers according to the seniority rule varies with firm size and was changed by the reform in 2001. In a firm with two employees, the least tenured worker had to be dismissed before the reform. After the reform the worker with shortest tenure can be exempted from the seniority rule so that the worker with longest tenure, that was safe before the reform, is dismissed. Consequently, the share of workers that came under risk of being dismissed in a firm with two workers is $50 \%$ and the share of workers that shared the risk is $50 \%$. All workers in firms with two and three employees were thereby affected by the reform. In a firm with four employees the worker with longest tenure is directly unaffected by the reform if one worker is to be dismissed. In the given scenario, the share of workers with no risk of being dismissed increases with firm size, see Table 6.

Table 6 Share of workers that came under risk, were directly unaffected or shared the risk due to the reform in 2001

\begin{tabular}{|c|c|c|c|c|c|c|c|}
\hline Size & $\begin{array}{l}\text { Came under } \\
\text { risk \% }\end{array}$ & $\begin{array}{c}\text { Directly } \\
\text { unaffected \% }\end{array}$ & $\begin{array}{c}\text { Shared the } \\
\text { risk \% }\end{array}$ & Size & $\begin{array}{c}\text { Came under } \\
\text { risk \% }\end{array}$ & $\begin{array}{c}\text { Directly } \\
\text { unaffected \% }\end{array}$ & $\begin{array}{c}\text { Shared } \\
\text { the risk \% }\end{array}$ \\
\hline 2 & 50 & 0 & 50 & 7 & 29 & 57 & 14 \\
\hline 3 & 66 & 0 & 33 & 8 & 25 & 63 & 12 \\
\hline 4 & 50 & 25 & 25 & 9 & 22 & 67 & 11 \\
\hline 5 & 40 & 40 & 20 & 10 & 20 & 70 & 10 \\
\hline 6 & 33 & 50 & 17 & & & & \\
\hline
\end{tabular}

Notes: Size refers to number of employees at a firm. All figures are based on the assumption of one job task-specific group per firm, one dismissal and that the seniority rule is strictly applied.

Because the share of workers that were directly affected by the softer employment protection decreases with firm size I expect the average effect to decrease with firm size. To test for firm size specific reform effects I estimate the following model

$$
Y_{i f t}=\alpha+\lambda_{t}+\sum_{f=2}^{20} \pi_{f} D_{i f t}+\sum_{f=2}^{20} \delta_{f}\left(D_{f t} \times \text { Post }_{i f t}\right)+u_{i f t}
$$


where $Y_{i f t}$ is the outcome for individual $i$ in firm $f$ at time $t, \lambda_{t}$ contains time effects and $D_{f t}$ indicates whether a person is employed in a firm of size $f$ at time $t$ or not. Post $t_{t}$ takes the value of one for periods from 2001 and onwards, and zero otherwise. Note that firms with 21 to 50 employees serve as the benchmark in the model. Figure 5 displays difference-in-difference estimates for the incidence and total days of parental leave and temporary leave for employees in firms with two to 20 employees. All estimates refer to the overall effect. A relative drop in parental childcare is estimated in smaller firms within the treatment group. A significant relative reduction is estimated in firms with two to seven employees. ${ }^{32}$ In firms with eight to ten employees the model fails to estimate an average reduction by paid parental childcare.


Figure 5 Firm size specific difference-in-difference estimates for firms with two to 20 employees

Notes: "Size" is to the number of employees in a firm. All models use individual data and standard errors are clustered at the firm level. Firms with 21 to 50 employees serve as the benchmark. "Effect" refers to firm-specific effects and "Upper/Lower" refers to a 95 percent confidence interval.

Moreover, when a firm can exempt two workers from the seniority rule more workers are at risk of being dismissed in firms with two to ten employees. However, in what way the individual worker was affected depends on the worker's relative tenure. In a scenario with one dismissal per firm, the reform implies that some workers came under risk for being dismissed, shared the dismissal risk with other workers or were unaffected by the reform, see Table 6. To examine differential effects, I estimate

\footnotetext{
${ }^{32}$ von Below and Skogman Thoursie (2010) estimate that only firms with at most five employees reduce their hiring while the effect on separations is independent of firm size.
} 
separate difference-in-difference models for groups of workers that came under risk, shared the risk or were directly unaffected. I calculate a worker's relative tenure in a firm in the spring of 2000 using employment information from 1995. Then, I analyze the years 2000 and 2001 where treatment status in the spring of 2000 instruments treatment status in 2001. Analyzing just one post year has the advantage that a worker's relative tenure is more stable. Table 7 presents the results. All estimates, besides for total days of parental leave, are statistically significant. The largest relative effect is estimated for workers who shared the dismissal risk with others; these workers were hired last so the reform implied a greater chance to remain employed, as they could be exempt from the seniority rule. In this group, the incidence of temporary parental leave drops by 34.5 percent relative the control group and the total days of temporary parental leave drops by 40.9 percent in the year of the reform. The parental leave incidence drops by 19.3 percent but no change in total days is estimated. A decline of parental childcare is also estimated for the group of workers who came under risk of being dismissed: the parental leave incidence declines by 12.1 percent and the temporary parental leave incidence drops by 14.3 percent and total days by 19.4 percent. In the group who were directly unaffected at times of one dismissal per firm, the parental leave incidence decreases by 5.1 percent and the temporary parental leave incidence decreases by 4.9 percent and total days by 5.7 percent. That paid parental childcare drops both among those who shared the dismissal risk and those who came under risk can be explained by the fact that the reform strengthened the link between an employee's productivity and continuation of the employment. 
Table 7 Behavioral reform effects by relative firm tenure

\begin{tabular}{|c|c|c|c|c|}
\hline & \multicolumn{2}{|c|}{ Parental leave } & \multicolumn{2}{|c|}{ Temporary parental leave } \\
\hline & Incidence & Total days & Incidence & Total days \\
\hline & (1) & (2) & (3) & (4) \\
\hline Shared the risk & $\begin{array}{c}-0.0111 * * \\
(0.0046)\end{array}$ & $\begin{array}{l}-0.9251 \\
(0.9556)\end{array}$ & $\begin{array}{c}-0.0394 * * * \\
(0.0056)\end{array}$ & $\begin{array}{c}-0.2904 * * * \\
(0.0626)\end{array}$ \\
\hline Relative change (\%) & -19.3 & -19.2 & -34.5 & -40.9 \\
\hline Pretreatment average & 0.0577 & 4.8221 & 0.1143 & 0.7096 \\
\hline Came under risk & $\begin{array}{c}-0.0078 * * * \\
(0.0023)\end{array}$ & $\begin{array}{c}-0.6544 \\
(0.5086)\end{array}$ & $\begin{array}{c}-0.0172 * * * \\
(0.0026)\end{array}$ & $\begin{array}{c}-0.1544 * * * \\
(0.0298)\end{array}$ \\
\hline Relative change (\%) & -12.1 & -9.9 & -14.3 & -19.4 \\
\hline Pretreatment average & 0.0647 & 6.5892 & 0.1203 & 0.7962 \\
\hline Directly unaffected & $\begin{array}{c}-0.0037 * * * \\
(0.0013)\end{array}$ & $\begin{array}{l}-0.5651^{*} \\
(0.3098)\end{array}$ & $\begin{array}{c}-0.0066^{* * *} \\
(0.0015)\end{array}$ & $\begin{array}{c}-0.0470 * * * \\
(0.0176)\end{array}$ \\
\hline Relative change (\%) & -5.1 & -7.9 & -4.9 & -5.7 \\
\hline Pretreatment average & 0.0725 & 7.1814 & 0.1345 & 0.8197 \\
\hline
\end{tabular}

Notes: Each estimate represents a separate model. $* * *, * *, *$ denote statistical significance at the 1,5 , and 10 percent levels, respectively. The changes in dismissal risk are based on a scenario where a firm with two to ten employees is to dismiss one employee and each firm represents one job-task specific dismissal group. The estimates for "Sharing dismissal risk" use 19,812 treated observations, the estimates for "Higher dismissal risk" 55,384 treated observations and the estimates for "Unchanged dismissal risk" use 159,613 treated observations. The relative change relates the effect to the pretreatment average.

The construction of the control group partly relies on a high firm size threshold (50 employees) to allow individuals to flow within the balanced sample, an important feature since the reform affected hires and separations. But how important is the choice of the upper limit of the control group for the validity of my results? Figure 6 presents separate reform effects for models where the upper firm size limit of the control group increases gradually in steps of five, from 15 to 50 employees. ${ }^{33}$ None of the previously estimated reform effects are sensitive to the selection of the upper limit of the control group.

\footnotetext{
${ }^{33}$ Individual data from a balanced panel data set are used for each estimate.
} 



Figure 6 Difference-in-difference estimates using different control groups

Notes: "Size” refers to the upper limit of the control group in terms of the number of employees in a firm. The dark line refers to reform effects and grey dashed lines to a 95 percent confidence interval.

The identification of the behavioral effect relies on the assumption that the treatment status as of the spring of 2000 was unaffected by the reform in 2001. The reform was discussed publicly as late as in the first half of 2000 and it was not until October in the same year that it was decided on. Treatment status in the spring of 2000 thereby seems to be a valid instrument; especially considering that matching on the labor market takes time. Nevertheless, I re-estimate the behavioral effect for parental leave and temporary parental leave using treatment status in 1997, 1998 and 1999, respectively, as instruments for later treatment status. Results are presented in Table 8. The results are in line with previous findings and I find no support that the estimate of the behavioral effect is driven by the choice of instrument. 
Table 8 Behavioral reform effects using different instruments

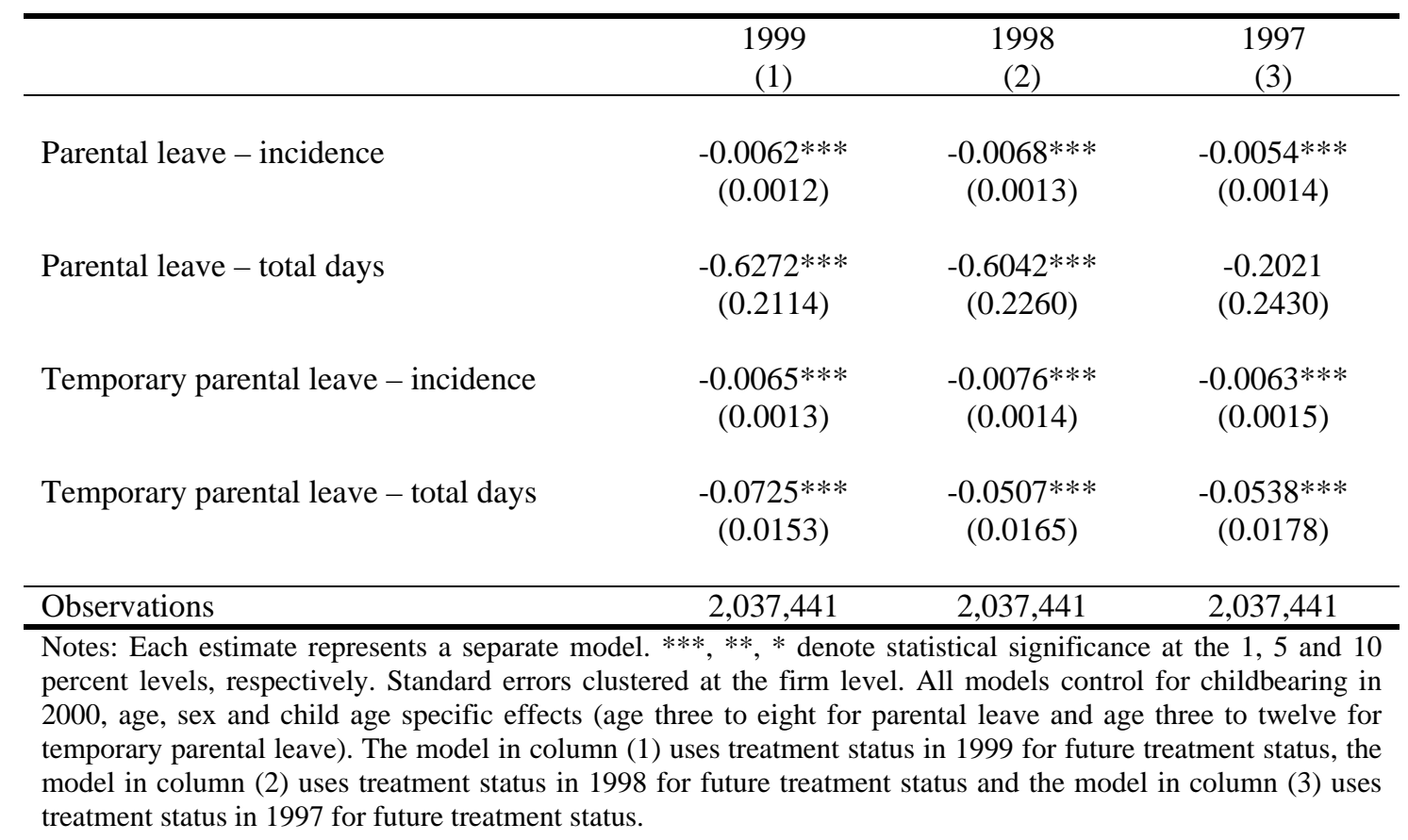

\section{Conclusion}

In this paper, I provide new evidence on how employment protection affects workers' absence behavior revealing that indirect economic incentives can have a substantial effect on how parents use and divide paid childcare between them. In Sweden, firms with at most ten employees were allowed to exempt two workers from the tenure based dismissal order in 2001. I compare paid parental childcare for workers in firms under and above the size threshold over time with the help of a difference-in-difference estimator. The results can be summarized as follows. The softer employment protection reduces the total days of paid parental leave among workers in small firms by 10.6 percent and the total days of temporary parental leave by 5.5 percent. A sorting effect and a behavioral effect can explain the reduction in childcare. The softer employment protection is also estimated to influence the distribution of paid childcare within some families: in families with one treated and one untreated parent, I estimate a general increase in childcare for the unaffected male partner. I interpret the reallocation of leave as if parents try to avoid an external effect on the child.

I conclude that the supply of childcare by working parents is influenced by the general employment protection legislation and that the division of parental childcare within families is partly based on indirect economic incentives. 


\section{References}

Albrecht, J. W., Eden, P-A., Sundström, M., and Vroman, S. B. (1999), “Career Interruptions and Subsequent Earnings: A Reexamination Using Swedish Data”, The Journal of Human Resources, 2, 294-311.

Amilon, A. (2007), "On the Sharing of Temporary Parental Leave: The Case of Sweden”, Review of Economic of the Household, 5, 385-404.

Arbetaren (2003), "Undantagsreglerna består", 21, May 21-29, www.arbetaren.se.

Autor, D. H., Kerr, R. W. and Kugler, D. A. (2007), “Does Employment Protection Reduce Productivity? Evidence from US States”, The Economic Journal, 117, 189217.

von Below, D. and Skogman Thoursie P. (2010), “Last in, first out?: Estimating the effect of seniority rules in Sweden”, Labour Economics, 17, 987-997.

Björklund, A. (2006), ”Does family policy affect fertility? Lessons from Sweden”, Journal of Population Economics, 1, 3-24.

Blundell, R., Chiappori, P., and Meghir, C. (2005), "Collective labor supply with children", Journal of Political Economy, 113, 1277-1306.

Browning, M. and Chiappori, P. (1998), "Efficient intra-household allocations: A general characterization and empirical tests." Econometrica. 66, 1241-1278.

Bygren, M. and Duvander, A.-Z. (2006), "Parents’ Workplace Situation and Fathers' Parental Leave Use", Journal of Marriage and Family, 68, 363-372.

Card, D., Ibarraràn, P. and Miguel Villa, J. (2011), "Building in an Evaluation Component for Active Labor Market Programs: A Practioner's Guide”, IZA DP No. 6085 .

Calleman, C. (1999), “Turordningsreglerna och flexibiliteten” Juridisk Tidskrift, 4, 808822.

Chiappori, P. and Ekeland, I. (2006), "The Microeconomics of Group behavior: General Characterization", Journal of Economic Theory, 130, 1-26.

Chiappori, P., Fortin, B., and Lacroix, G. (2002), "Marriage market, divorce legislation, and household labor supply", Journal of Political Economy, 110, 37-72. 
Delacroix, A. (2003), “Transitions into Unemployment and the Nature of Firing Costs”, Review of Economic Dynamics, 3, 651-671.

Donald, S. G., and Lang, K. (2007), "Inference with Difference in Differences and Other Panel Data”, Review of Economics and Statistics, 89, 221-33.

Duvander, A-Z. and Sundström, M. (2002), "Gender Division of Childcare and the Sharing of Parental Leave among New Parents in Sweden", European Sociological Review, 18, 433-447.

Edin, P-A. and Holmlund, B. (1993), "Effekter av anställningsskydd", SOU:1993:32.

Ekberg, J. Eriksson, R. and Friebel, G. (2005), “Parental Leave - A Policy Evaluation of the Swedish “Daddy Month” reform”, IZA Discussion Paper, No. 1617.

Engellandt, A. and Riphahn, T. R. (2005), "Temporary Contracts and Employee Effort", Labour Economics, 12, 281-299.

Hopenhayn, H. and Rogerson, R. (1993), “Job Turnover and Policy Evaluation: A General Equilibrium Analysis”, Journal of Political Economy, 5, 915-938.

Ichino, A. and Riphahn T. R. (2004). ”Absenteeism and Employment Protection: Three Case Studies”, Swedish Economic Policy Review, 11, 95-114.

Ichino, A. and Riphahn T. R. (2005). ”The Effect of Employment Protection on Worker Effort: Absenteeism during and after Probation”, Journal of the European Economic Association, 3, 120-143.

Jacob, B. A. (2010). “The Effect of Employment Protection on Worker Effort: Evidence from Public Schooling”, NBER Working Paper, No. 15655.

Kugler, D. A. and Saint-Paul, G. (2004), “How Do Firing Costs Affect Worker Flows in a World with Adverse Selection”, Journal of Labor Economics, 3, 553-584.

Lalive, R. and Zweimüller, J. (2009), "Does Parental Leave Affect Fertility and Returnto-Work? Evidence from Two Natural Experiments”, The Quarterly Journal of Economics, 24, 1363-1402.

Lazear, P. E. (1990), “Job Security Provision and Employment”, The Quarterly Journal of Economics, 3, 699- 726.

Lindbeck, A, Palme, M. and Persson, M. (2006), "Job Security and Work Absence: Evidence from a Natural Experiment”, Working paper, Stockholm University. 
Mortensen, D. T. and Pissarides, C. A. (1999), "New Developments in Models of Search in the Labor Market”, in Handbook of Labor Economics, vol 3, edited by Ashenfelter, O. and Card, D., Amsterdam: North Holland, 1999.

OECD (2010), "Gender Brief", OECD Social Policy Division.

Olsson, M. (2009), “Employment Protection and Sickness Absence”, Labour Economics, 16, 208-214.

Parys, J. and Schwerhoff, G. (2010), "Efficient Intra-Household Allocation of Parental Leave”, IZA Dicusssion Paper, No. 5113.

Pries, M. and Rogerson, R. (2005), "Hiring Policies, Labor Market Institutions, and Labor Market Flows”, Journal of Political Economy, 3, 811-839.

Riphahn, R. and Thalmaier, A. (2001), "Behavioral Effects of Probation Periods: An Analysis of Worker Absenteeism", Journal of Economic and Statistics, 221, 179201.

Skyt-Nielsen, H. (2009), “Causes and Consequences of a Father's Child Leave: Evidence from a Reform of Leave Schemes”, IZA Discussion Paper, No. 4267.

Swedish National Insurance Board (2004), Flexibel föräldrapenning - hur mammor och pappor använder föräldraförsäkringen och hur länge de är föräldralediga, RFV analyserar.

Wasmer, E. (2006), ” General versus Specific Skills in Labor Markets with Search Frictions and Firing Costs”, American Economic Review, 3, 811-831. 


\section{Appendix}

Tabell A 1 Results using firm aggregated data

\begin{tabular}{|c|c|c|c|c|}
\hline & \multicolumn{2}{|c|}{ Parental leave } & \multicolumn{2}{|c|}{ Temporary parental leave } \\
\hline & Incidence & Total days & Incidence & Total days \\
\hline & $(1)$ & $(2)$ & (3) & (4) \\
\hline Total effect & $\begin{array}{c}-0.0071^{* * *} \\
(0.0011)\end{array}$ & $\begin{array}{c}-0.8394 * * * \\
(0.2143)\end{array}$ & $\begin{array}{c}-0.0077 * * \\
(0.0014)\end{array}$ & $\begin{array}{c}-0.0622 * * * \\
(0.0154)\end{array}$ \\
\hline $\begin{array}{l}\text { Total effect controlling for childbearing in } \\
\text { 2000, age and child age specific effects }\end{array}$ & $\begin{array}{c}-0.0040 * * * \\
(0.0010)\end{array}$ & $\begin{array}{c}0.5439 * * * \\
(0.2077)\end{array}$ & $\begin{array}{l}-0.0011 \\
(0.0012)\end{array}$ & $\begin{array}{l}-0.0146 \\
(0.0143)\end{array}$ \\
\hline $\begin{array}{l}\text { IV controlling for childbearing in } 2000 \text {, } \\
\text { age and child age specific effects }\end{array}$ & $\begin{array}{c}-0.0084 * * * \\
\quad(0.0013)\end{array}$ & $\begin{array}{l}-1.0287 * * * \\
(0.2664)\end{array}$ & $\begin{array}{l}-0.0064^{* * *} \\
(0.0015)\end{array}$ & $\begin{array}{c}-0.0436^{* *} \\
(0.0180)\end{array}$ \\
\hline Pretreatment average & 0.0629 & 6.9768 & 0.1277 & 0.8188 \\
\hline Observations OLS & 503,896 & 503,896 & 503,896 & 503,896 \\
\hline Observations IV & 447,403 & 447,403 & 447,403 & 447,403 \\
\hline
\end{tabular}

Notes: Each estimate represents a separate model. ***, **, * denote statistical significance at the 1, 5 and 10 percent levels, respectively. Standard errors are clustered at the firm level. IV uses treatment status in 2000 as an instrument for later treatment status.

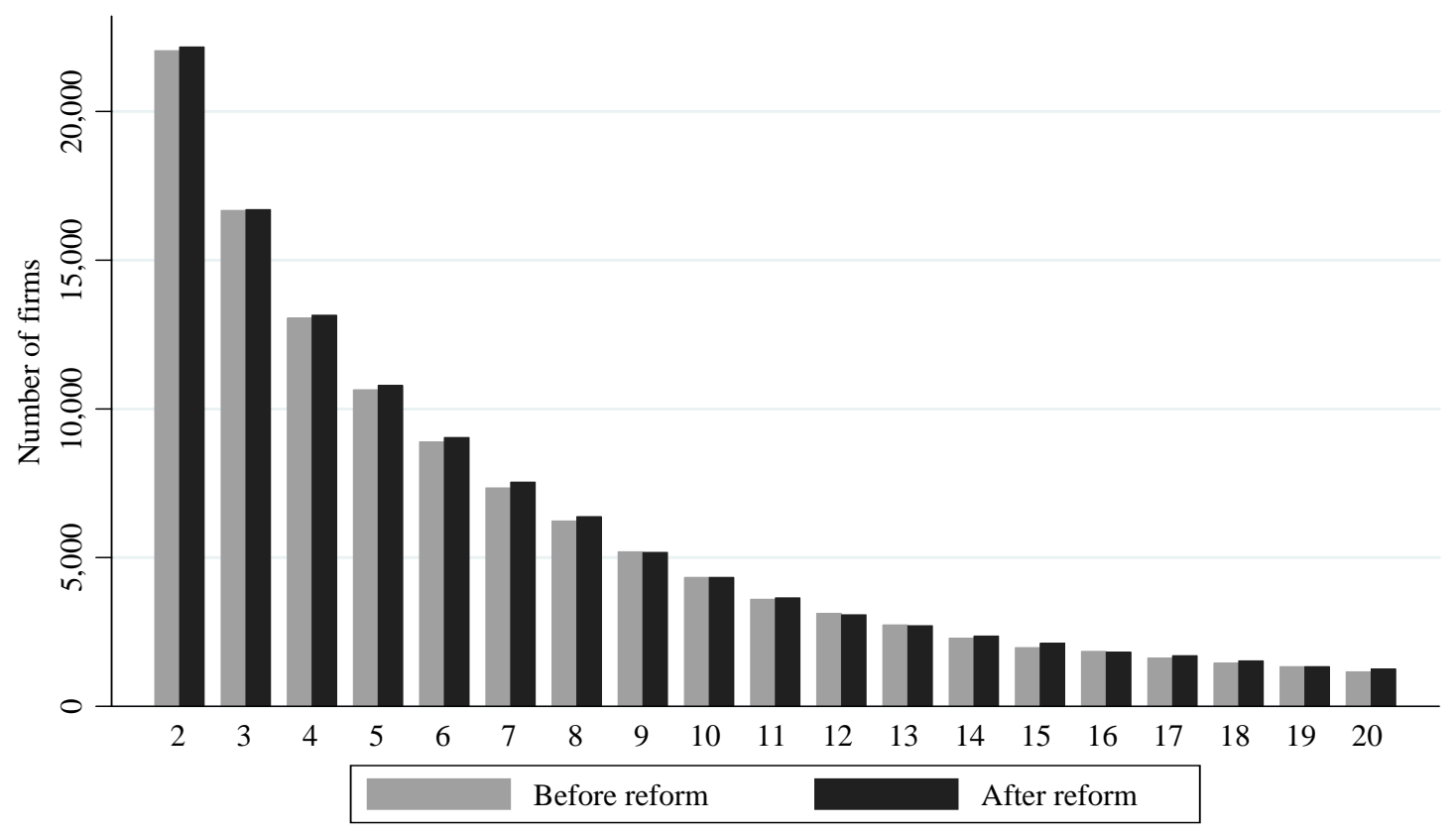

Figure A1 Firm size distribution before and after the reform

Notes: "Before reform" refers to the average number of firms of a given size in the years 1999 and 2000. "After reform” refers to the average number of firms of a given size in the years 2001 and 2002. 